\title{
COMPOSING THE MIXTURE OF A.CORDIFOLIA LEAF EXTRACT IN ELIMINATING SALMONELLA TYPHI
} AND STAPHYLOCOCCUS AUREUS BACTERIA

\author{
Wawan Sofwan Zaini ${ }^{1}$, Nining Kurniati ${ }^{2}$, Betty Nurhayati ${ }^{3}$, Cecep Dani Sucipto ${ }^{4}$, Ismi Rajiani ${ }^{5}$ * \\ ${ }_{1,2,4}$ Analyst Health Program of the Ministry of Health Polytechnic Banten, Indonesia \\ ${ }^{3}$ The Ministry of Health Polytechnic Bandung, Indonesia \\ ${ }^{5}$ Post Graduate Program of Muhammadiyah University Gresik, Indonesia
}

Article Info: Received 20 September 2019; Accepted 10 October 2019

DOI: https://doi.org/10.32553/ijmbs.v3i10.621

Corresponding author: Ismi Rajiani

Conflict of interest: No conflict of interest.

\begin{abstract}
Background: A.cordifolia leaf is one of the traditional medicinal plants that have many benefits, including cough medicine, diabetes, shortness of breath, burns, post-operative wounds, dysentery, kidney inflammation, inflammation of the intestine, acne, bleeding gums, smoothing menstruation, increase appetite, and increase endurance. This research aims to find out the minimum concentration of A.cordifolia leaf extract that was able to kill bacteria Salmonella typhi

Methods: This research is an experimental laboratory study with a research design using a Completely Randomized Design (CRD) in which the treatment of test bacteria is carried out with variations in concentration and contact time of the A.cordifolia leaf extract and A.cordifolia leaf using alcohol extract. The controlled variable was the concentration of A.cordifolia leaf extract with contact time variation while the response variable was the result of bacterial colony growth. For negative control applied sterilized aqua (0\%) and as a comparison chloramphenicol was used.

Result: The results showed that A.cordifolia which extracted by ethanol solvent killed bacteria S. Typhi at a concentration of $80 \%$ with a contact time of 10 minutes, and bacteria S. aureus at a level of $100 \%$ with a contact time of 10 minutes, whereas A.cordifolia water extract could kill bacteria S.typhi at a concentration $80 \%$ with a contact time of 20 minutes, and bacteria S. aureus at a concentration of $100 \%$ with a contact time of 20 minutes.

Conclusion: A.cordifolia, which extracted by ethanol solvent, has a stronger killing power than one extracted with water solvent.
\end{abstract}

Keyword: A.cordifolia leaves, Salmonella typhi, Staphylococcus aureus, extraction

\section{Introduction:}

In this modern era, people's lifestyles which pay less attention to environmental cleanliness have resulted in the emergence of infectious diseases. Nowadays, the motto of back to nature is often touted, ranging from living behavior, eating patterns, to the treatment of diseases. In curing various diseases, medicinal plants have become a demand that is much in market by the community, because besides being safe, the costs incurred are relatively inexpensive compared to drugs that are based on synthesis. The use of chemical medicines has side effects that can be either direct or indirect side effects or accumulate. This happens because chemicals are inorganic and pure while the body is organic and complex. Then chemicals are not materials that are genuinely suitable for the body. The use of chemicals in the body is considered as something that is unavoidable and is of limited use that can be accepted and tolerated by the body.

In various regions in Indonesia, many plants can be used for the treatment of multiple diseases, one of which is A.cordifolia (Anredera cardifolia). The content in the A.cordifolia leaves antioxidant activity, ascorbic acid, and high total phenols. ${ }^{1}$ These substances can fight Gram-positive bacteria such as Staphylococcus aureus. And able to also fight six Gram-negative bacteria such as Enterobacter cloacae, Escherichia coli, Klebsiella pneumonia, Pseudomonas aeruginosa, Serratia marcescens, and Enterobacter aerogenes. $^{2}$

A.cordifolia leaves contain a variety of active substances, namely alkaloids, saponins, flavonoids and polyphenols which have antibacterial power. ${ }^{3}$ In Indonesia, bacterial infectious diseases are still a health problem, especially in areas with poor sanitation and individual hygiene. Then it is necessary to develop a natural material that can be used as an 
alternative treatment, one of which is A.cordifolia leaves. The use of A.cordifolia leaves in the community for treatment has long been used, but scientific research needs to be done to show the efficacy and the right dose. An antibacterial activity test of ethanol extract and A.cordifolia leaf water extracts has been conducted to kill Salmonella typhi and Staphylococcus aureus by determining the minimum concentration with contact time variation using serial dilution.

The method In general, A.cordifolia leaves can accelerate health recovery after surgery, childbirth, circumcision, all internal injuries, intestinal inflammation, smooth and normalize circulation and blood pressure, prevent strokes, ulcers, gout, increase and restore vitality to the immune system, vizier (hemorrhoid), smooth urination, bowel movements, diabetes, typhoid fever, back pain, and others. $^{4}$

Typhoid fever is a contagious disease in the community caused by infection with bacteria Salmonella typhi. Typhoid fever is found in many countries, or areas that do not maintain cleanliness both water and food. The highest typhoid fever infection is often found in children ${ }^{5}$. Infection can occur through the mouth, from eating and drinking contaminated with bacteria Salmonella typhi. Foods that are usually tainted include cakes containing milk sauce, minced meat, poultry sausages, and eggs. Although infectious and sick people can contaminate food and drink, the source of infection by bacteria Salmonellosis is low-level animals. Many species of bacteria Salmonella occur naturally in chickens, turkeys, ducks, rodents, cats, dogs, and many other animals. These individuals can extract millions of bacteria Samonella in their stools which are sources of food and drink pollutants either directly or through flies as vectors. Typhoid fever if not treated immediately, can cause death of $10-20 \%$. Because there is an ulcer in the small intestine, where intestinal perforation, intestinal bleeding, toxemia, and other complications occur.

Based on the background above in previous studies, the minimum concentration of A.cordifolia leaf extract that was able to kill bacteria Salmonella typhi was at an extract concentration of $60 \%$ with a contact time of 60 minutes and in bacteria $S$. aureus was a concentration of $100 \%$ with a contact time of 90 minutes, while the minimum concentration of A.cordifolia leaf juice that can kill bacteria Salmonella typhi is at $80 \%$ concentration with a contact time of 180 minutes, and the bacteria S. aureus is $100 \%$ with a contact time of 60 minutes. Thus, further research was conducted to determine the lowest concentration of ethanol extract and A.cordifolia leaf water extract which can kill bacteria Salmonella typhi and Staphylococcus aureus.

\section{METHODS}

This study was an experimental laboratory study with a research design using a Completely Randomized Design (CRD) in which the treatment of test bacteria was carried out with variations in concentration and contact time of the A.cordifolia leaf Extract and Alcohol Extract. The controlled variable was the concentration of A.cordifolia leaf extract with contact time variation while the response variable was the result of bacterial colony growth. For negative control using sterile aquades $(0 \%)$ and as a comparison used chloramphenicol.

\section{RESULTS}

The results of the ethanol extract of A.cordifolia leaves against bacteria S.typhi, and compared with controls showed that at $80 \%$ concentration with a contact time of 10 minutes, ethanol extract was still able to kill S.typhi. Whereas at a concentration of $60 \%$ with all variations of contact time, there was no killing power against S.typhi, which was marked by the growth of bacterial colonies on SS agar media (Table 1).

Table 1: Testing of Ethanol Extract of A.cordifolia leaves against S.typhi with contact time variations

\begin{tabular}{|c|c|c|c|c|c|c|c|c|c|}
\hline \multirow[t]{3}{*}{ Concentration of A.cordifolia Extract (\%) } & \multicolumn{7}{|c|}{ CONTACT TIME (MIN) } & \multirow[t]{3}{*}{ CONTROL POSITIVE } & \multirow[t]{3}{*}{ CONTROL NEGATIVE } \\
\hline & \multicolumn{2}{|c|}{10} & \multicolumn{2}{|c|}{20} & \multicolumn{2}{|l|}{30} & 40 & & \\
\hline & 1 & 2 & 1 & 2 & 1 & 2 & 1 & & \\
\hline & - & - & - & & - & & - & + & - \\
\hline 60 & - & - & - & & - & & - & 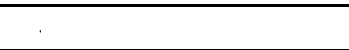 & \\
\hline 80 & & + & + & & + & & + & & \\
\hline 100 & & + & + & & + & & + & & \\
\hline
\end{tabular}


For the test results of A.cordifolia leaf water extract against bacteria S.typhi, and compared with controls it was seen that water extract at a concentration of $80 \%$ with a contact time of 10 minutes, could not kill S.typhi. Their killing power is only seen at $80 \%$ concentration with a contact time of 20 minutes. While at a concentration of $60 \%$ with all variations of contact time, there is no ability to kill against S.typhi, which is characterized by the growth of bacterial colonies on SS agar media. (Table 2)

Table 2: Testing the extract of water leaves against A.cordifolia S.typhi with contact time variations

\begin{tabular}{|c|c|c|c|c|c|c|c|c|c|c|}
\hline \multirow[t]{3}{*}{ Concentration (\%) } & \multicolumn{8}{|c|}{ CONTACT TIME (MINUTE) } & \multirow[t]{3}{*}{ POSITIVE } & \multirow[t]{3}{*}{ CONTROLS NEGATIVE CONTROLS } \\
\hline & \multicolumn{2}{|c|}{10} & \multicolumn{2}{|c|}{20} & \multicolumn{2}{|c|}{30} & \multicolumn{2}{|l|}{40} & & \\
\hline & 1 & 2 & 1 & 2 & 1 & 2 & 1 & 2 & & \\
\hline 40 & - & - & - & - & - & - & -- & -- & + & - \\
\hline 60 & - & - & - & - & - & - & - & - & & \\
\hline 80 & - & - & + & + & + & + & + & + & & \\
\hline 100 & + & + & + & + & + & + & + & + & & \\
\hline
\end{tabular}

The results of the ethanol extract of A.cordifolia leaves against the bacteria S.aureus using Mannitol Salt Agar germination media and compared with controls showed that at a concentration of $\leq 80 \%$ with all contact time, ethanol extract could not kill S.aureus. The killing power of $S$. aureus was only seen at a concentration of $100 \%$ with a contact time of 10 minutes, which was characterized by the absence of growth of bacterial colonies on MSA media (Table 3).

Table 3: Testing of ethanol extract of A.cordifolia leaves against $S$. aureus with the variation of contact time

\begin{tabular}{|c|c|c|c|c|c|c|c|c|c|c|}
\hline \multirow[t]{3}{*}{ Concentration (\%) } & \multicolumn{8}{|c|}{ CONTACT TIME (MINUTE) } & \multirow[t]{3}{*}{ POSITIVE } & \multirow[t]{3}{*}{ CONTROL NEGATIVE CONTROL } \\
\hline & \multicolumn{2}{|c|}{10} & \multicolumn{2}{|c|}{20} & \multicolumn{2}{|c|}{30} & \multicolumn{2}{|c|}{40} & & \\
\hline & 1 & 2 & 1 & 2 & 1 & 2 & 1 & 2 & & \\
\hline 40 & - & - & - & - & - & -- & -- & -- & + & - \\
\hline 60 & -- & - & - & - & - & - & - & - & & \\
\hline 80 & - & - & - & - & - & - & - & - & & \\
\hline 100 & + & + & + & + & + & + & + & ++ & & \\
\hline
\end{tabular}

The test results of $A$.cordifoli leaf water extracted with a variation of contact time against the bacteria S.aureus and compared with control showed that at a concentration of $\leq 80 \%$ with all contact time, and a concentration of $100 \%$ with a contact time of 10 minutes the water extract could not kill S.aureus. The killing power of S. aureus is only seen at a concentration of $100 \%$ with a contact time of 20 minutes, which is characterized by the absence of bacterial colony growth on MSA media (Table 4).

Table 4: Testing the extract of A.cordifolia leaf water against S.aureus with variations in contact time

\begin{tabular}{|c|c|c|c|c|c|c|c|c|c|c|}
\hline \multirow[t]{3}{*}{ Concentration (\%) } & \multicolumn{8}{|c|}{ CONTACT TIME (MINUTE) } & \multirow[t]{3}{*}{ POSITIVE } & \multirow[t]{3}{*}{ CONTROL NEGATIVE CONTROL } \\
\hline & \multicolumn{2}{|l|}{10} & \multicolumn{2}{|c|}{20} & \multicolumn{2}{|c|}{30} & \multicolumn{2}{|l|}{40} & & \\
\hline & 1 & 2 & 1 & 2 & 1 & 2 & 1 & 2 & & \\
\hline 40 & - & - & - & - & - & - & $\begin{array}{l}- \\
\end{array}$ & -- & + & - \\
\hline 60 & -- & - & - & - & - & - & - & - & & \\
\hline 80 & - & - & - & - & - & - & - & - & & \\
\hline 100 & - & - & + & + & + & + & + & ++ & & \\
\hline
\end{tabular}

\section{DISCUSSION}

Biological activity of water-soluble flavonoid compounds against bacteria by destroying the cytoplasmic membrane of bacteria consisting of amino acids and lipids and reacting them with alcohol groups found in flavonoid compounds. ${ }^{6}$ From this process will cause cell walls damaged and compounds into the bacterial cell nucleus. Furthermore, this compound will contact with DNA in the nucleus of bacterial cells and through differences in polarity between the constituent DNA lipids and alcohol groups in flavonoid compounds will occur reactions that damage the lipid structure of bacterial DNA so that it will undergo lysis and die. ${ }^{7}$

The damaged cell wall condition will immediately decompose, followed by penetration of phenol into 
the bacterial cell and cause protein coagulation. ${ }^{8}$ Besides, bioactive phenol compounds can also cause cell lysis and cause protein denaturation. Some saponins have a nature like soap which is a compound of "Surfactant agent" is durable and has a structure that can bind to hydrophilic molecules and organic molecules non-polar (lipophilic) to damage the cytoplasmic membrane and kill the bacteria. ${ }^{9}$

Additionally, obtained experimental results show that the antibacterial power of ethanol extract is higher than the anti-bacterial power of water extract. This is because the content of active compounds in ethanol extracts and water extracts is different, namely in ethanol extracts more energetic compounds are dissolved/extracted in ethanol solvents compared to water extracts, such as flavonoid compounds, polyphenols are more easily extracted in ethanol solvents, so the power the antibacterial properties of ethanol extract are more significant than the antibacterial power of water extracts. ${ }^{10}$

The results of previous study showed that A.cordifolia leaf extract had a minimum kill concentration of $50 \%$ against S.aureus. The previous study concluded that A.cordifolia (Anredera cordifolia) leaf extracts with concentrations of $3 \%, 5 \%, 7 \%, 9 \%, 11 \%$, and $13 \%$ were only bacteriostatic, which inhibited the growth of bacteria Vibrio harveyi with the best concentration obtained, which was $13 \%{ }^{2}$ Furthermore, the results previous research showed that the extract of A.cordifolia leaves at $75 \%$ concentration was the most effective concentration as an antibacterial against E. coli, followed by a concentration of $50 \%$ and a concentration of $25 \% .{ }^{11}$

A.cordifolia leaf extract has the ability to inhibit the growth of bacteria Propionibacterium acnes seen by the inhibition zone formed. The most effective concentration to inhibit the growth of Propionibacterium acnes is at a concentration of $100 \%$ at $9.00 \mathrm{~mm}$ at 24 hours and $11.20 \mathrm{~mm}$ at 48 hours. ${ }^{12}$ An extract of A.cordifolia leaves at a concentration of $60 \%$ with a contact time of 60 minutes can kill S.typhi, and at $100 \%$ with a contact time of 90 minutes. Can kill bacteria $S$. aureus while A.cordifolia leaf juice at $80 \%$ concentration with 180 minutes contact time can kill S.typhi, and at $100 \%$ concentration with 60 minutes contact time can kill the bacteria S.aureus

\section{CONCLUSION}

A.cordifolia leaf extract (Ethanol and Water) has antibacterial activity and can kill the bacteria Salmonella typhi and Staphylococcus aureus. The minimum concentration of Ethanol Extract of A.cordifolia leaves that can kill the bacteria S. Typhi is $80 \%$ with a contact time of 20 minutes and the bacteria S. aureus is $100 \%$ with a contact time of 10 minutes The minimum concentration of water extract of A.cordifolia leaves that is capable of killing the bacteria S. Typhi is on $80 \%$ concentration with contact time of 10 minutes, and the bacteria S.aureus are $100 \%$ with contact time of 20 minutes. A.cordifolia leaf extract with ethanol solvent has stronger antibacterial activity than A.cordifolia extract with water solvent.

\section{DECLARATION}

Funding: No funding sources

Conflict of interest: None declared

Ethical approval: Ethical clearance was obtained from The Ministry of Health Polytechnic Banten, Indonesia.

\section{REFERENCES}

1. Sukandar EY, Kurniati NF, Nurdianti AN. Antiobesity Effect of ethanol extract of andredera cordifolia (ten) steenis leaves on obese male wistar rats induced by high-carbohydrate diet. Int J Pharm Pharm Sci, 2016; 8 (4): 171-173.

2. Rusmana $D$, Elizabeth $M$, Widowati $W$, Fauziah $N$, Maesaroh M. Inhibition of inflammatory agent production by ethanol extract and eugenol of Syzygium aromaticum (L.) flower bud (clove) in LPSstimulated Raw 264.7 cells. Res J Med Plant. 2015; 9: 264-74.

3. Dewi K, Widyarto B, Erawijantari PP, Widowati W. In vitro study of Myristica fragrans seed (Nutmeg) ethanolic extract and quercetin compound as antiinflammatory agent. Int J Res Med Sci. 2015; 3: 2303 10.

4. Kang CH, Choi YH, Choi IW, Lee JD, Kim GY. Inhibition of lipopolysaccharide-induced iNOS, COX-2 and TNF-a expression by aqueous extract of orixa japonica in RAW 264.7 cells via supression of NF-kB activity. Trop J Pharmaceut Res. 2011; 10: 161-68.

5. Ashley EA, Lubell Y, White NJ, Turner P. Antimicrobial susceptibility of bacterial isolates from community acquired infections in Sub-Saharan Africa and Asian low and middle income countries. Trop Med Int Health. 2011;16(9):1167-79.

6. Nakamura A, Osonoi T, Terauchi Y. Relationship between urinary sodium excretion and pioglitazoneinduced edema. J Diabetes Investig. 2010;1(5):20811. 
7. Lalhminghlui $K$, Jagetia GC. Evaluation of the freeradical scavenging and antioxidant activities of Chilauni, Korth . Future Sci OA. 2018;4(2):FSO272.

8. Zarei L, Peiravian F, Pishvaee MS, Aghababaei B. The Scarce Drugs Allocation Indicators in Iran: A Fuzzy Delphi Method Based Consensus. Iran J Pharm Res. 2019;18(2):1126-1135.

9. Martins S, Mussatto SI, Martínez-avila G, Montañezsaenz J, Aguilar CN, Teixeira JA. Bioactive phenolic compounds: production and extraction by solid-state fermentation. A review. Biotechnol Adv. 2011;29 (3):365-73.
10. Botalova A, Bombela T, Zubov P, Segal M, Korkotian E. The flavonoid acetylpectolinarin counteracts the effects of low ethanol on spontaneous network activity in hippocampal cultures. J Ethnopharmacol. 2019;229:22-28.

11. Bijelic A, Aureliano $M$, Rompel A. The antibacterial activity of polyoxometalates: structures, antibiotic effects and future perspectives. Chem Commun (Camb). 2018;54(10):1153-1169.

12. Muluye RA, Bian $Y$, Alemu PN. Anti-inflammatory and Antimicrobial Effects of Heat-Clearing Chinese Herbs: A Current Review. J Tradit Complement Med. 2014;4(2):93-8. 